\title{
MENINGKATKAN MINAT BELAJAR MATEMATIKA SISWA MELALUI MODEL PEMBELAJARAN KOOPERATIF TIPE INDEX CARD MATCH PADA SISWA KELAS XI MIPA I SMA NEGERI I TANJUNG SELOR
}

\author{
YATINI \\ SMAN 1 Tanjung Selor Kalimantan Utara \\ E-mail : Buyatini@gmail.com
}

\begin{abstract}
ABSTRAK
Meningkatkan Minat Belajar Matematika Siswa Melalui Model Pembelajaran Kooperatif Tipe Index Card Match Pada Siswa Kelas XI MIPA I SMA Negeri ITanjung Selor.Penelitian ini bertujuan untuk meningkatkan minat belajar matematika siswa melalui model pembelajaran kooperatif tipe index card match pada siswa kelas XI MIPA I SMA Negeri 1 Tanjung Selor. Jenis penelitian ini adalah penelitian tindakan kelas. Subjek penelitian ini adalah siswa kelas XI IPA I SMA Negeri 1 Tanjung Selor yang terdiri dari 17 siswa laki-laki dan 16 siswa perempuan. Teknik pengumpulan data dalam penelitian ini adalah menggunakan lembar observasi dan penilaian diri. Penelitian tindakan kelas ini dilaksanakan dalam 2 siklus dan setiap siklus dilaksanakan dalam 2 kali pertemuan. Hasil penelitian menunjukkan bahwa minat belajar matematika siswa pada siklus I adalah $74 \%$ siswa berada pada minimal kategori tinggi dan siklus II mengalami peningkatan menjadi $85 \%$ siswa berada pada minimal kategori tinggi. Berdasarkan hasil penelitian dapat disimpulkan bahwa dengan menggunakan model index card match dapat meningkatkan minat belajar matematika pada siswa kelas XI-1 SMA Negeri 1 Tanjung Selor.
\end{abstract}

Kata Kunci : Minat Belajar Matematika, Model Pembelajaran kooperatif Index Card Match

\section{ABSTRACT}

Increasing Students' Interest in Learning Mathematics Through Cooperative Learning Model Type Index Card Match in Class XI MIPA I SMA Negeri I Tanjung Selor. This study aims to increase students' interest in learning mathematics through cooperative learning model type index card match in class XI MIPA I SMA Negeri 1 Tanjung Selor. This type of research is classroom action research. The subjects of this study were students of class XI IPA I SMA Negeri 1 Tanjung Selor which consisted of 17 male students and 16 female students. Data collection techniques in this study were using observation sheets and self-assessment. This classroom action research was carried out in 2 cycles and each cycle was carried out in 2 meetings. The results showed that the students' interest in learning mathematics in the first cycle was $74 \%$ of students in the high category at least and the second cycle increased to $85 \%$ of the students in the high minimum category. Based on the results of the study, it can be concluded that using the index card match model can increase interest in learning mathematics in class XI1 students of SMA Negeri 1 Tanjung Selor.

Keywords: Interest in Learning Mathematics, Cooperative Learning Model Index Card Match

\section{PENDAHULUAN}

Undang-undang nomor 20 Tahun 2003 tentang sistem pendidikan nasional menyebutkan bahwa pendidikan nasional bertujuan untuk mengembangkan potensi peserta didik agar menjadi manusia yang beriman dan bertakwa kepada Tuhan Yang Maha Esa, berakhlak mulia, sehat, berilmu, cakap, kreatif, mandiri dan menjadi warga negara yang demokratis dan bertanggung jawab. Khususnya dalam pelajaran matematika dimana pelajaran matematika memiliki fungsi mengajarkan pola pikir kritis pada peserta didik, mengajar peserta didik untuk kreatif dan mampu memecahkan masalah dalam kehidupan sehari- hari yang berhubungan dengan pelajaran matematika.

Proses belajar mengajar matematika akan terasa menyenangkan apabila terdapat sekumpulan siswa yang dapat memiliki rasa ketertarikan yang mendalam pada suatu materi 
yang sedang dipelajari khususnya dalam mata pelajaran matematika. Dengan kata lain siswa yang memiliki ketertarikan atau minat belajar yang tinggi dapat mempengaruhi suasana kelas agar proses pembelajaran dapat berjalan seperti yang diharapkan serta mampu menciptakan suasana kelas yang menyenangkan. Minat salah satu sifat yang relatif menetap pada diri seseorang. Seseorang dapat melakukan pekerjaan atau tugas jika seseorang memiliki minat. Dengan minat ia akan melakukan sesuatu yang diminatinya. Sebaliknya tanpa minat seseorang tidak mungkin melakukan sesuatu.

Dengan terpenuinya minat, sesorang tidak mungkin melakukan sesuatu. Dengan terpenuinya minat, sesorang akan mendapatkan kesenangan dan kepuasan batin yang dapat menimbulkan motivasi. Menurut Sumiati (2009:238) menyatakan bahwa tingkat pencapaian kemampuan dan keberhasilan belajar sangat ditentukan oleh minat siswa terhadap mata pelajaran. Siswa yang mempunyai minat dapat diharapkan akan mencapai prestasi belajar yang optimal.

Namun pada kenyataannya bahwa matematika menjadi salah satu mata pelajaran yang banyak dihindari siswa. Banyak siswa yang beranggapan bahwa matematika itu sulit. Hal ini terlihat ketika siswa siswa ada yang berbicara dengan teman sebangku, mengantuk, mengganggu teman, keluar masuk kelas secara bergantian dengan berbagai macam alasan dan lain sebagainya. Siswa cenderung tidak tertarik, tidak ingin tahu, tidak suka dan tidak memiliki peran penuh sebagai siswa yang seharusnya menerima ilmu. Selain itu model pembelajaran yang digunakan oleh guru kurang menarik minat siswa sehingga memicu terjadinya kejenuhan pada diri siswa.

Berdasarkan wawancara yang dilakukan pada tanggal 05 Januari 2020 pada guru matematika di SMA Negeri 1 Tanjung Selor untuk mata pelajaran matematika, menyatakan bahwa dari 33 siswa di kelas X IPA I pada saat semester 2 sekitar $16 \%$ siswa yang memiliki ketertarikan dalam pembelajaran atau 5 orang. Ketertarikan ini terlihat pada saat guru menjelaskan materi pelajaran di depan, siswa tersebut aktif bertanya dan aktif dalam mengemukakan pendapat mengenai penjelasan guru di depan dan juga terlihat ketika siswa yang lainnya mengantuk, ngobrol dan mengganggu teman bahkan ada siswa yang tidak membawa buku matematika dan tidak mengerjakan pekerjaan rumah.

Berdasarkan observasi yang dilakukan langsung oleh peneliti pada siswa kelas XI IPA-1 pada semester I di SMA Negeri 1 pada tanggal 22 Maret 2020, pada menit pertama pembukaan pembelajaran, dilakukan pengecekan pekerjaan rumah dan siswa menyiapkan pekerjaan rumah namun suasana kelas ramai karena ada yang tidak mengerjakan pekerjaan rumah. Pada tahap pengujian hasil pekerjaan rumah, siswa dipersilahkan untuk maju kedepan mengerjakan tanpa membawa hasil pekerjaannya.

Terbukti bahwa siswa tidak dapat mengerjakan tugas tersebut kemungkinan besar karena hasil pekerjaannya adalah hasil contekan dari siswa yang lain. Ada sekitar $90 \%$ atau 28 orang siswa sibuk mencari jawaban dalam keadaan panik dan hanya sekitar 10\% atau 5 siswa yang bersikap santai kemungkinan karena siswa tersebut telah memahami materi tersebut. Ketika dilakukan pe mbahasan di depan mengenai hasil pekerjaan siswa, hanya sekitar $16 \%$ atau 5 orang dengan suara nyaring menjawab langkah pengerjaan dan siswa yang lain hanya diam, mengantuk, ngobrol, mencoret- coret buku, dan mengganggu teman.

Ketika masuk dalam pembahasan materi baru, sekitar 19\% atau 6 siswa memperhatikan namun tidak mengerti karena malu bertanya dan siswa yang lainnya tidur-tiduran dan mencoretcoret dibuku serta siswa yang lain mengobrol dikelas. Pada saat siswa diberikan pertanyaan mengenai sejauh mana pemahaman mereka, tidak ada satupun siswa yang berani mengatakan sudah paham atau belum mengenai materi yang baru. Pada tahap pemberian tugas latihan, terlihat hanya 19\% yaitu 6 siswa yang mengerjakan soal latihan sendiri dan yang lainnya menunggu jawaban, bahkan dalam hal ini siswa tidak mau bertanya mengenai apa yang belum dipahami sehingga suasana kelas agak ramai karena saling menunggu jawaban. Ketika siswa diminta untuk maju kedepan mengerjakan hanya $10 \%$ atau 3 orang yang berani mengacungkan tangan dan pada saat salah satu siswa tersebut maju mengerjakan sekitar $16 \%$ atau 5 orang 
memperhatikan, $32 \%$ atau 10 orang menyalin pekerjaan teman didepan tanpa memikirkan benar atau salah jawaban tersebut sedangkan siswa yang lain sibuk mengobrol, tidur-tiduran dan lainlain. Pada proses penyimpulan akhir pelajaran, sekitar $81 \%$ atau 25 siswa sibuk menutup bukunya dengan segera dan menyimpannya serta tidak mendengarkan hasil kesimpulan. Selain itu dari nilai ulangan harian siswa didapati bahwa dari 31 siswa hanya $13 \%$ atau 4 siswa yang mencapai nilai KKM yang telah ditentukan di SMAN 1 Tanjung Selor yaitu 75.

Berdasarkan masalah yang nampak pada hasil wawancara dan observasi maka dapat dikatakan bahwa minat belajar siswa rendah pada mata pelajaran matematika. Hal ini terlihat dari tidak adanya ketertarikan siswa pada proses pembelajaran matematika. Adanya rasa tidak suka yang seringkali ditunjukkan siswa saat pembelajaran matematika. Didapatinya rasa ketidakingintahuan terhadap matematika yang terlihat ketika siswa tidak memahami materi namun siswa tidak berani bertanya. Salah satu penyebab siswa tidak berminat pada mata pelajaran matematika adalah karena proses pembelajaran yang kurang menyenangkan dan kurang mampu menarik perhatian siswa. Hal ini diketahui ketika peneleti melakukan obervasi kepada guru matematika di SMA Negeri 1 Tanjung Selor di kelas XI MIPA-1. Guru menggunakan metode ceramah tetapi tidak mampu menarik perhatian siswa. Siswa terlihat jenuh dan bosan saat proses pembelajaran.

Melihat fakta yang ada, maka salah satu solusi yang diduga dapat meningkatkan minat belajar siswa dalam proses pembelajaran matematika yaitu dengan diterapkannya model pembelajaran kooperatif tipe index card match. Index card match adalah salah satu strategi untuk meninjau ulang materi pelajaran dengan teknik mencari pasangan kartu index yang merupakan jawaban atau soal sambil belajar mengenai suatu konsep atau topik dalam suasana menyenangkan. Dengan penerapan model pembelajaran kooperatif tipe index card match maka perasaan gembira dapat tumbuh pada diri siswa, selain itu model pembelajaran tersebut dapat menciptakan suasana belajar yang aktif dan menyenangkan serta mampu menarik perhatian siswa.

Berdasarkan masalah yang nampak pada hasil wawancara dan observasi maka peneliti tertarik untuk mengangkat judul penelitian meningkatkan minat belajar matematika siswa melalui model pembelajaran kooperatif tipe index card match pada siswa kelas XI-1 SMA Negeri 1Tanjung Selor.

Belajar merupakan aktivitas manusia untuk mendapatkan perubahan dalam dirinya. Belajar dapat dilakukan dengan berlatih atau mencari pengalaman baru. Dengan demikian, belajar dapat membawa perubahan bagi

seseorang, baik berupa pengetahuan,sikap, maupun keterampilan. Kegiatan belajar dan mengajar di sekolah terjadi sebuah proses yaitu interaksi antara guru dengan siswa, siswa dengan siswa jika terjadi kegiatan belajar kelompok. Dalam interaksi tersebut akan terjadi sebuah proses pembelajaran.

Hamdani (2010:292) menyatakan bahwa minat mempengaruhi proses hasil belajar yang juga berpengaruh terhadap motivasi. Kalau seorang tidak berminat untuk mempelajari sesuatu, dia tidak dapat diharapkan akan berhasil dengan baik dalam mempelajari hal tersebut. Sebaliknya, kalau sesorang mempelajari sesuatu sesuai dengan minatnya, ia akan berhasil lebih baik. Minat seseorang terhadap suatu hal dapat dilihat dari keinginanya untuk mengetahui atau belajar lebih banyak. Oleh karena itu, guru harus mengetahui minat siswa terhadap suatu mata pelajaran dan megetahui cara menarik perhatian siswa terhadap pelajaran.

salah satu solusi yang diduga dapat meningkatkan minat belajar siswa dalam proses pembelajaran matematika yaitu dengan diterapkannya model pembelajaran kooperatif tipe index card match. Robert dalam Tampubolon (2014:112) menyatakan bahwa index card match model pasangan kartu indekx yang dapat digunakan oleh guru dalam pembelajaran dikelas. Model ini merupakan pembelajaran kooperatif, karena dalam pembelajaran siswa melakukan kegiatan secara bersama-sama dengan berpasangan dengan diarahkan oleh guru, sehingga siswa saling membantu, saling berdiskusi, dan saling beragumentasi dalam rangka mengasah pengetahuan yang mereka kuasai saat itu, dan menutup kesenjangan pemahaman masing- 
masing.

Menururut Siberman (2009:240) index card match adalah cara menyenangkan lagi aktif untuk meninjau ulang materi pelajaran. Index card match membolehkan peserta didik untuk berpasangan dan memainkan kuis dengan kawan sekelas. Index card match (mencari pasangan) adalah suatu strategi pembelajaran yang mengajak siswa untuk belajar aktif dan bertujuan agar siswa mempunyai jiwa kemandirian dalam belajar serta menumbuhkan daya kreatifitas. Silberman (2009:239) bahwa salah satu cara paling meyakinkan untuk menjadikan belajar tepat adalah menyertakan waktu untuk meninjau apa yang telah dipelajari. materi yang telah dibahas oleh siswa cenderung lima kali lebih melekat didalam pikiran ketimbang materi yang tidak diulang.

Langkah-langkah index card match menurut Zaini (2008: 68) antara lain:

1. Buatlah potongan-potongan kertas sejumlah peserta didik yang ada dalam kelas

2. Bagi jumlah kertas-kertas tersebut menjadi dua bagian yang sama

3. Tulis pertanyaan tentang materi yang telah diberikan sebelumnya pada setengah bagian kertas yang telah disiapkan. Setiap kertas berisi satu pertanyaan

4. Pada separo kertas yang lain, tulis jawaban dari pertanyaan-pertanyaan yang tadi dibuat

5. Kocoklah semua kertas sehingga tercampur antara soal dan jawaban

6. Beri setiap peserta didik satu kertas. Jelaskan bahwa ini adalah aktivitas yang dilakukan berpasangan. Separo peserta didik akan mendapat soal dan yang lain akan mendapatkan jawaban

7. Minta peserta didik untuk menemukan pasangan mereka. Jika ada yang sudah menemukan pasangan, minta mereka untuk duduk berdekatan. Terangkan juga agar mereka tidak memberitahu materi yang mereka dapatkan kepada teman yang lain

8. Setelah semua peserta didik menemukan pasangan dan duduk berdekatan, minta pasangan secara bergantian untuk membacakan soal yang diperoleh dengan keras kepada temanteman yang lain. selanjutnya soal tersebut dijawab oleh pasangan-pasangan yang lain

9. Akhiri proses ini dengan membuat klarifikasi dan kesimpulan

Adapun kelebihan dan kelemahan dari index card match menurut Tampubolon (2014:113) adalah sebagai berikut :

a. Kelebihan

1) Suatu model yang mengandung unsur permainan, kebersamaan, dan membangun keakraban antarsiswa

2) Model yang dapat digunakan untuk mengetahui sejauh mana tingkat

pemahaman siswa terhadap materi pelajaran yang telah diberikan oleh guru.

3) Siswa yang belum menguasai materi yang telah dibelajarkan tentunya akan mengalami kesulitan dalam mencari pasangannya

b. Kelemahan

1) Mebutuhkan waktu yang lama bagi siswa untuk menyelesaikan tugas dan prestasi

2) Guru harus meluangkan waktu yang lebih

3) Lama untuk membuat persiapan

4) Guru harus memiliki jiwa demokratis dan keterampilan yang memadai dalam hal pengelolaan kelas

5) Menuntut siswa tertentu dari siswa atau kecenderungan untuk bekerja sama dalam menyelesaikan masalah

6) Suasana kelas menjadi gaduh sehingga dapat mengganggu kelas lain

\section{METODE PENELITIAN}

Jenis penelitian ini adalah penelitian tindakan kelas (PTK) yang dilakukan secara kolaborasi bersama guru yang bertujuan untuk mengembangkan minat belajar matematika siswa pada kelas XI MIPA I SMA Negeri 1 Tanjung Selor. Penelitian ini dilaksanakan pada kelas XI MIPAI di SMA Negeri 1 Tanjung Selor yang terdiri dari 17 siswa laki-laki dan 16 siswa perempuan. Prosedur penelitian dalam penelitian ini direncanakan pada 2 siklus. Dimana setiap siklunya 
dilakukan dalam dua kali pertemuan. Prosedur dari penelitian ini terdiri dari empat langkah menurut Kemmis dan Mc Taggart yaitu perencanaan, pelaksaan, observasi, dan refleksi. Setiap tahap pelaksanaan termuat dalam setiap siklus. Siklus berhenti apabila peneliti dan guru sepakat bahwa penelitian yang dilakukan sesuai dengan rencana dan minat belajar matematika siswa kelas XI MIPA I SMA Negeri 1 Tanjung Selor telah mengalami peningkatan.

\section{HASIL DAN PEMBAHASAN}

\section{Hasil}

Jenis penelitian yang dilakukan merupakan penelitian tindakan kelas dengan menerapkan model pembelajaran kooperatif tipe index card match untuk menigkatkan minat belajar matematika siswa kelas XI MIPA I pada materi Persamaan Kuadrat. Penelitian dilaksanakan di SMA Negeri 1 Tanjung Selor yang beralamat Jalan Kol, Soetadji No 6, Kecamatan Tanjung Selor tepatnya di kelas XI MIPA I.

Subjek penelitian sebanyak 33 siswa, terdiri dari 17 siswa laki laki dan 16 siswa perempuan. Penelitian dilaksanakan dalam 2 siklus, meliputi siklus I dan siklus II. Setiap siklus terdiri dari dua kali pertemuan dengan alokasi waktu 2 x 45 menit. Peneliti dalam penelitian ini bertindak sebagai guru dan ada 5 observer yang dipilih yaitu teman sejawat. Setiap siklus dalam penelitian ini meliputi empat tahap, yaitu: (1) perencanaan, (2) tindakan, (3) observasi, dan (4) refleksi. Secara rinci hasil penelitian akan dipaparkan secara berurutan setiap siklus, sebagai berikut:

\section{Siklus I}

\section{Tahap observasi}

Tahap observasi dilaksanakan bersamaan dengan tindakan kelas. Pada tahap ini, pengamatan pelaksanaan pembelajaran dilaksanakan oleh 5 orang pengamat yaitu 5 orang teman sejawat. Observer mengamati kegiatan aktivitas guru, dan minat belajar matematika siswa pada saat pembelajaran yang berlangsung selama kegiatan siklus 1 yaitu pertemuan 1 dan 2. Adapun hasil observasi selama penelitian adalah sebagai berikut:

Tabel 1. Observasi Minat Belajar Siklus 1 Pertemuan ke-1

\begin{tabular}{|c|c|c|c|}
\hline $\begin{array}{l}\text { Skala } \\
\text { Rentang }\end{array}$ & $\begin{array}{l}\text { Banyak } \\
\text { Siswa }\end{array}$ & $\begin{array}{l}\text { Persen } \\
\text { tase } \\
(\%) \\
\end{array}$ & Kategori \\
\hline \multicolumn{2}{|c|}{$3,1 \leq X \leq 4,00$} & $\overline{0}$ & $\begin{array}{l}\text { Sangat } \\
\text { Tinggi }\end{array}$ \\
\hline \multicolumn{2}{|c|}{$2,1 \leq X<3,111$} & 35 & Tinggi \\
\hline \multicolumn{2}{|c|}{$1,1 \leq X<2,122$} & 65 & Rendah \\
\hline \multicolumn{2}{|c|}{$0,1 \leq \mathrm{X}<1,10$} & 0 & $\begin{array}{l}\text { Sangat } \\
\text { Rendah }\end{array}$ \\
\hline
\end{tabular}

Tabel 2. Observasi Minat Belajar Siklus 1 Pertemuan ke-2

\begin{tabular}{llll}
\hline $\begin{array}{l}\text { Skala } \\
\text { Rentang }\end{array}$ & $\begin{array}{l}\text { Banyak } \\
\text { Siswa }\end{array}$ & $\begin{array}{l}\text { Persen } \\
\text { tase } \\
(\boldsymbol{\%})\end{array}$ & Kategor i \\
$3,1 \leq \mathrm{X} \leq 4,0$ & 1 & $\overline{3}$ & $\begin{array}{l}\text { Sangat } \\
\text { Tinggi }\end{array}$ \\
$2,1 \leq \mathrm{X}<3,1$ & 17 & 55 & Tinggi \\
\hline
\end{tabular}




\begin{tabular}{llll}
\hline $1,1 \leq \mathrm{X}<2,1$ & 13 & 35 & Rendah \\
$0,1 \leq \mathrm{X}<1,1$ & 2 & 6 & $\begin{array}{l}\text { Sangat } \\
\text { Rendah }\end{array}$ \\
Jumlah & 33 & 100 & \\
\hline
\end{tabular}

\section{Tahap refleksi}

Setelah dilaksanakannya kegiatan siklus I, selanjutnya diadakan refleksi untuk mengevaluasi jalannya tindakan berdasarkan hasil pengamatan observer. Berdasarkan refleksi yang dilakukan terhadap siklus I, pembelajaran dengan menggunakan model pembelajaran kooperatif tipe index card match sudah berjalan sesuai prosedur yang telah direncanakan. Namun ada beberapa tahap yang diperoleh pada siklus I pada pertemuan ke-1 dan ke-2 yang masih tergolong rendah, dikarenakan terdapat beberapa masalah yang harus diselesaikan agar pada siklus II dapat diperbaiki. Adapun kekurangan dan kelebihan guru maupun siswa pada saat proses belajar mengajar pada siklus I adalah sebagai berikut:

1) Pada pertemuan ke-1 keadaan kelas masih sangat ribut karena peneliti yang berperan sebagai guru belum mampu memberikan motivasi kepada siswa untuk semangat dalam mengikuti proses pembelajaran.

2) Masih ada siswa yang ngobrol dengan teman sebangku dan tidur-tiduran sehingga tidak memperhatikan materi yang dijelaskan oleh guru

3) Terdapat siswa yang kesulitan dalam mencari pasangan atau mencocokkan kartu karena tidak memahami materi akibatnya siswa kurang antusias dan saling menunggu pasangan untuk datang mencocokkan

4) Peneliti belum menerapkan sistem hukuman bagi siswa yang yang tidak menemukan pasangan sampai batas waktu habis sehingga siswa masih ada yang acuh tak acuh pada kartu yang didapatkan

5) Peneliti belum memberikan reword sebagai penghargaan bagi siswa yang tercepat dalam menemukan pasangannya

6) Peneliti sulit untuk mengelolah kelas saat siswa sedang mencari pasangan kartu karena ada siswa yang sekedar ikut-ikutan teriak untuk mencari pasangan kartu. Hal ini diketahui ketika guru meminta siswa yang teriak untuk menjawab apa kartu yang didapatkan dan siswa tersebut tidak dapat menjawab.

7) Siswa kelihatan jenuh ketika setiap pasangan diminta untuk maju membacakan soal dan jawaban yang didapatkan akibatnya siswa mengantuk mengobrol dll

8) Banyak siswa yang sering membicarakan jam bahwa jam pelajaran telah habis padahal jam pelajaran masih banyak, hal ini karena siswa kurang terlibat saat pasangan yang lain maju untuk membacakan dan menuliskan soal dan jawaban yang didapatkan

9) Adanya siswa yang lambat masuk kedalam kelas sehingga mempengaruhi proses pembelajaran saat masuk dalam tahap mencocokkan kartu karena siswa yang lambat masuk secara otomatis harus mendapatkan kartu baru dari guru. Hal ini akan memudahkan siswa tersebut dalam menemukan pasangannya karena pasangan kartu yang didapatkan hanya ada pada siswa yang baru masuk kedalam kelas

10) Peneliti kurang memperhatikan waktu sehingga tidak memiliki waktu dalam menyimpulkan hasil pembelajaran

11) Peneliti memberitahu jawaban kepada siswa saat siswa bertanya mengenai benar atau salah kartu yang didapatkan, hal ini membuat siswa tergantung dan berharap kepada guru saat siswa mulai kesulitan padahal siswa tersebut belum mencoba untuk mencocokkan kartu yang didapatkan

12) Peneliti belum mampu mengaitkan materi dalam kehidupan sehari-hari sehingga siswa masih kesulitan memahami materi dan mengerjakan tugas yaitu soal yang diberikan pada kartu index

13) Beberapa siswa tidak mencatat sama sekali saat proses pembelajaran karena siswa tersebut 
hanya sekedar berdiri dan mencari pasangan tanpa mencoba untuk mengerjakan soal yang ada pada kartu yang didapatkan.

'Setelah melaksanakan siklus I dengan 2 kali pertemuan, diperoleh hasil akhir (rekapitulasi) minat belajar matematika siswa yang dapat di lihat pada tabel berikut 5 ini:

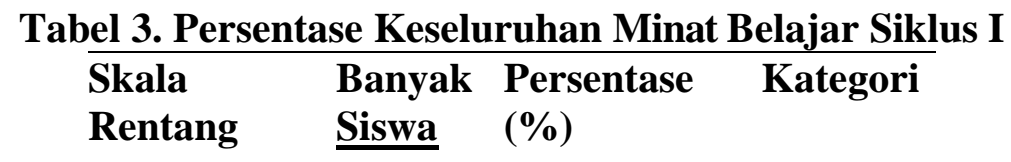

$\begin{array}{llll}3,1 \leq X \leq 4,0 & \overline{1} & 3 & \begin{array}{l}\text { Sangat } \\ \text { Tinggi }\end{array} \\ 2,1 \leq X<3,1 \quad 24 & 74 & \begin{array}{l}\text { Tinggi } \\ \text { Rendah }\end{array} \\ 1,1 \leq X<2,1 \quad 8 & 26 & \begin{array}{l}\text { Sangat } \\ \text { Rendah }\end{array} \\ 0,1 \leq X<1,1 \quad 0 & 0 & \end{array}$

Pada siklus I terdapat 1 siswa atau sebesar 3\% berada pada kategori sangat tinggi dengan interval 3,1 $\leq X \leq 4,0$. Sebanyak 24 siswa atau $74 \%$ berada pada kategori tinggi dengan interval $2,1 \leq \mathrm{X}<3,1$. Sebanyak 8 siswa atau sebesar $26 \%$ berada pada kategori rendah. Hasil penelitian pada siklus I menunjukkan bahwa persentase minat belajar matematika adalah $74 \%$ siswa berada pada kategori minimal tinggi, sedangkan indikator keberhasilan yang disyaratkan adalah $\geq 75 \%$ siswa berada dalam kriteria minimal kategori tinggi. Peneliti memutuskan penelitian tindakan kelas pada aspek minat belajar siswa dilanjutkan ke siklus II karena belum sesuai dengan indikator keberhasilan yang diharapkan dalam penelitian ini.

Berdasarkan hasil penelitian yang dilaksanakan pada siklus I menunjukkan bahwa indikator keberhasilan dalam penelitian ini belum tercapai, maka penelitian perlu dilanjutkan ke siklus II yaitu dengan melaksanakan tindakan perbaikan antara lain: 1). Guru membuat peraturan selama proses pembelajaran seperti menghukum siswa yang tidak menemukan pasangannya agar siswa yang lain serius dalam mencocokkan kartu. 2) guru memberikan motivasi kepada siswa dengan cara memberikan skor bagi pasangan yang aktif selama proses pembelajaran. 3) guru harus memperhatikan waktu agar setiap langkah dalam proses pembelajaran dapat terlaksana secara maksimal. 4) guru meminta siswa agar mencatat setiap soal yang dibacakan oleh pasangan yang maju. Dalam hal ini guru menyampaikan bahwa catatan tersebut merupakan bagian dari penilaian sehingga siswa dapat mencatat setiap materi yang dipresentasikan oleh pasangan yang lain.

\section{Siklus II}

\section{Tahap observasi}

Tahap observasi dilaksanakan bersamaan dengan tindakan kelas. Pada tahap ini, pengamatan pelaksanaan pembelajaran dilaksanakan oleh 5 orang pengamat yaitu 5 orang teman sejawat. Observer mengamati kegiatan aktivitas guru, dan minat belajar matematika siswa pada saat pembelajaran yang berlangsung selama kegiatan siklus II yaitu pertemuan 1 dan 2 . Adapun hasil observasi selama penelitian diuraikan sebagai berikut:

Tabel 4. Observasi Minat Belajar Siklus II pertemuan ke-1

\begin{tabular}{|c|c|c|c|}
\hline $\begin{array}{l}\text { Skala } \\
\text { Rentan }\end{array}$ & $\begin{array}{l}\text { Banyak } \\
\text { Siswa }\end{array}$ & $\begin{array}{l}\text { Persen tase } \\
(\%)\end{array}$ & $\begin{array}{l}\text { Katego } \\
\text { ri }\end{array}$ \\
\hline $\begin{array}{l}\text { g } \\
3,1 \leq X \leq 4,0\end{array}$ & 0 & 0 & $\begin{array}{l}\text { Sangat } \\
\text { Tinggi }\end{array}$ \\
\hline $2,1 \leq X<3,1$ & 26 & 84 & Tinggi \\
\hline
\end{tabular}




\begin{tabular}{llll}
\hline $1,1 \leq \mathrm{X}<2,1$ & 5 & 16 & $\begin{array}{l}\text { Renda } \\
\mathrm{h}\end{array}$ \\
$0,1 \leq \mathrm{X}<1,1 \quad 0$ & 0 & $\begin{array}{l}\text { Sangat } \\
\text { Renda } \\
\mathrm{h}\end{array}$ \\
Jumlah & 31 & 100 & \\
\hline
\end{tabular}

Tabel 5. Observasi Minat Belajar Siklus II pertemuan ke-2

\begin{tabular}{llll}
$\begin{array}{l}\text { Skala } \\
\text { Rentan } \\
\mathbf{g}\end{array}$ & $\begin{array}{l}\text { Banyak } \\
\text { Siswa }\end{array}$ & $\begin{array}{c}\text { Persen tase } \\
(\boldsymbol{\%})\end{array}$ & Kategori \\
$3,1 \leq \mathrm{X} \leq 4,0$ & 0 & 0 & $\begin{array}{l}\text { Sanga } \\
\mathrm{t}\end{array}$ \\
& & & $\begin{array}{l}\text { Tingg } \\
\mathrm{i}\end{array}$ \\
$2,1 \leq \mathrm{X}<3,1$ & 26 & 84 & $\begin{array}{l}\text { Tinggi } \\
\text { Rendah }\end{array}$ \\
$1,1 \leq \mathrm{X}<2,1$ & 5 & 16 & $\begin{array}{l}\text { Sangat } \\
\text { Rendah }\end{array}$ \\
$0,1 \leq \mathrm{X}<1,1$ & 0 & 0 & \\
Jumlah & 31 & 100 & \\
\hline
\end{tabular}

\section{Tahap refleksi}

Setelah dilaksanakannya kegiatan siklus II, selanjutnya diadakan refleksi untuk mengevaluasi jalannya tindakan berdasarkan hasil pengamatan observer. Berdasarkan refleksi yang dilakukan pada siklus II, pembelajaran dengan menggunakan model pembelajaran kooperatif tipe index card match sudah berjalan sesuai prosedur yang telah direncanakan. Adapun kelebihan guru maupun siswa pada saat proses belajar mengajar pada siklus II adalah sebagai berikut:

1) Siswa mulai menunjukkan perasaan senang terhadap pelajaran matematika

2) Siswa tidak lagi merasa bosan dan mengantuk saat proses pembelajaran karena siswa belajar dengan cara berpindah dari tempat duduk untuk mencocokkan kartu

3) Siswa terlihat sangat antusias dalam mencocokkan kartu selama proses pembelajaran sedang berlangsung

4) Siswa dapat mempelajari semua kartu soal karena dipresentasikan oleh setiap pasangan

5) Guru hanya sebagai pembimbing jalannya diskusi sehingga guru tidak perlu menyampaikan materi secara keseluruhan tetapi siswa yang berperan penting dalam mempelajari materi yang didapatkan

6) Komunikasi antara siswa lebih terbuka dan membuat siswa nyaman dalam belajar Setelah melaksanakan siklus II dengan 2 kali pertemuan, diperoleh hasil akhir (rekapitulasi) minat belajar matematika siswa.

Tabel 6. Persentase Keseluruhan Minat Belajar Siklus II

$\begin{array}{llll}\begin{array}{l}\text { Skala } \\ \text { Rentang }\end{array} & \begin{array}{l}\text { Banyak Persent ase } \\ \text { Siswa }\end{array} & \begin{array}{l}\text { Kategor } \\ (\%)\end{array} \\ 3,1 \leq \mathrm{X} \leq 4,0 \overline{0} & 0 & \begin{array}{l}\text { Sangat } \\ \text { Tinggi }\end{array} \\ 2,1 \leq \mathrm{X}<3,126 & 84 & \begin{array}{l}\text { Tinggi } \\ \text { Rendah }\end{array} \\ 1,1 \leq \mathrm{X}<2,15 & 16 & \end{array}$




\begin{tabular}{lll}
\hline $0,1 \leq X<1,10$ & 0 & Sangat \\
Rendah
\end{tabular}

Jumlah $\quad 31 \quad 100$

Berdasarkan tabel 4. 16 Pada siklus II terdapat 5 siswa atau sebesar $16 \%$ berada pada kategori rendah dengan interval $1,1 \leq X<2,1$. Sebanyak 26 siswa atau $84 \%$ berada pada kategori tinggi dengan interval $2,1 \leq X<3,1$. Hasil penelitian pada siklus II menunjukkan bahwa persentase minat belajar matematika adalah $84 \%$ siswa berada pada kategori minimal tinggi, sedangkan indikator keberhasilan yang disyaratkan adalah $\geq 75 \%$ siswa berada dalam kriteria minimal kategori tinggi. Dengan demikian peneliti memutuskan untuk menghentikan penelitian tindakan kelas karena telah sesuai dengan indikator keberhasilan yang diharapkan dalam penelitian ini.

\section{KESIMPULAN}

Model pembelajaran kooperatif tipe index card match dapat meningkatkan minat belajar matematika siswa kelas XI IPA SMA Negeri 1 Tanjung Selor tahun pembelajaran 2015/2016. Hasil Penelitian menunjukkan bahwa minat belajar siswa pada siklus I adalah $74 \%$ siswa berada pada minimal kategori tinggi dan siklus II mengalami peningkatan menjadi $84 \%$ siswa berada pada minimal kategori tinggi. Sedangkan dalam meningkatkan minat belajar matematika siswa terlihat saat proses pembelajaran

menggunakan index card match siswa begitu tertarik dan antusias dalam mencocokkan kartu yang didapatkan.

Model pembelajaran kooperatif tipe index card match lebih menarik karena saat belajar siswa mencari pasangan kartu sambil bermain. Selain itu index card match juga merupakan suatu model yang mengandung unsur permainan, kebersamaan, dan membangun keakraban, dan kerjasama antarsiswa. Sehingga selama proses pembelajaran menggunakan model pembelajaran kooperatif tipe index card match perasaan gembira dan ketertarikan siswa pada pembelajaran matematika dapat meningkat. Dalam penerapan model index card match, siswa merasa tidak jenuh karena siswa lebih banyak meninggalkan tempat duduk dan bergerak leluasa dan berpikir secara keras. Index card match membuat siswa terbiasa aktif mengikuti pembelajaran sehingga minat siswa dapat meningkat.

Ciri khas lain dari index card match yang mampu meningkatkan minat belajar siswa yaitu materi yang dibelajarkan merupakan materi yang telah dipelajari siswa sebelumnya. Suatu materi yang telah dipelajari sebelumnnya biasanya membuat siswa lebih cenderung respon saat dibelajarkan. Sehingga pada saat diterapkannya model index card match siswa begitu tertarik dan antusias dalam proses pembelajaran.

Agar siswa lebih tertarik dan semangat saat proses pembelajaran, peneliti menambahkan sistem perebutan kursi yang telah diberi nomor sebanyak pasangan dalam kelas XI MIPA I serta peneliti menerapkan sistem hukuman bagi siswa yang tidak dapat menemukan pasangannya. Selama proses pembelajaran, siswa begitu antusias dan semangat dalam mencocokkan kartu dan berlomba-lomba merebutkan kursi nomor 1, 2, 3 dan seterusnya menurut kecepatan siswa dalam menemukan pasangannya.

\section{DAFTAR PUSTAKA}

Arikuntono, Suhardjono Suharsimi. (2015). Pendidikan Tindakan Kelas. Jakarta: Bumi Aksara. Calvin, Fauriza. (2015). Pengaruh Minat Belajar dan Motivasi Belajar Terhadap Hasil Belajar Matematika Siswa Kelas IX SMP Negeri 5 Tarakan Dengan Kemandirian Belajar Sebagai Variabel Moderator. Skripsi, Hal 160

Danim, Sudarwan. (2013). Perkembangan Peserta Didik. Bandung: ALFABETA.

Darmadi, Hamid. (2015). Desain dan Implementasi Penelitian Tindakan Kelas (PTK). Bandung: ALFABETA. 
Daryanto. (2009). Panduan Proses Pembelajaran Kreatif dan Inovatif. Jakarta: AV Publizer. Djaali. (2013). Psikologi Pendidikan. Jakarta: Bumi Aksara.

Djamarah, Syaiful Bahri. (2011). Psikologi Belajar. Jakarta: Rineka Cipta.

Ekawarna. (2013). Penelitian Tindakan Kelas (Edisi Revisi). Jakarta: GP Press Group.

Ferryansyah. (2010). Perbandingan Prestasi Belajar Matematika Siswa Antara Pembelajaran yang Disertai Penciptaan Kondisi Alfa dan Tanpa Disertai Kondisi Alfa. Skripsi.

Hamdani. (2010). Strategi Belajar Mengajar, Bandung: CV Pustaka Setia.

Harzono, Rudi. (2013). Ragam Model Mengajar yang Inovatif. Jokjakarta: Diva Press.

Jhon. (2006). Matematika Sekolah Dasar dan Menengah Pengembangan Pengajaran. Jakarta: Erlangga.

Kunandar. (2013). Penelitian Tiindakan Kelas. Jakarta: KDT.

Latipah, Eva. (2012). Pengantar Psikologi Pendidikan. Yogyakarta: PT Pustaka Insan Madani.

Nugraheni, Aninditya Sri. (2012). Penerapan Strategi Kooperatif Learning. Yogyakarta: PT Pustaka Insan Madani.

Rusman. (2012). Model-model Pembelajaran. Jakarta: PT Raja Gratin.

Sadirman. (2012). Interaksi dan Motivasi Belajar Mengajar. Jakarta: Rajawali Pers

Sanjaya, Wina. (2006). Strategi Pembelajaran. Jakarta: Kencana.

Shoimin, Aris. (2014). Model Pembelajaran Inovatif Dalam Kurikulum 2013. Yogyakarta: ARRUZZ Media.

Silberman, Mel. (2014). Active Learning 101 Strategi Pembelajaran Aktif. Yogyakarta: Pustaka Insan Madani.

Slameto. (2010). Belajar dan Faktor-faktor yang Mempengaruhinya. Jakarta: Rineka Cipta

Sumiati. (2009). Metode Pembelajaran. Bandung: CV Wacana Prima.

Suprihatin, Eni dkk. (2013). Penerapan Metode Index Card Match Dalam Peningkatan Pembelajaran Bilangan Romawi Siswa Kelas IV SDN 2

Susanta, Ahmad. (2012). Teori Belajar Pembelajaran di SD, Jakarta: Kencana Prenada Media Group.

Tampubolon, Saur. (2014). Penelitian Tindakan Kelas Sebagai Pengembangan Profesi Pendidik dan Keilmuan. Yogyakarta: PT. Gelora Aksara Pratama

Suprihatin, Eni. (2012). Penerapan Metode Index Card Match Dalam Peningkatan Pembelajaran Bilangan Romawi Siswa Kelas IV SDN 2 Wonorejo Kecamatan Karanganyar Tahun 2012/2013. Jurnal.

Zamzah. (2012). Model-model Pembelajaran Menciptakan Proses Belajar Mengajar yang Kreatif dan Efektif. Jakarta: Bumi Aksara. 